\title{
ANALISIS DAMPAK SEGREGASI GENDER DI PESANTREN TERHADAP PERILAKU SANTRI
}

\section{Thoriq Aziz Jayana}

IAIN Madura, Jl. Raya Panglegur No.Km. 4, Barat, Ceguk, Tlanakan, Kabupaten Pamekasan, Jawa Timur 69371

Email: azizjthoriq@yahoo.com

\begin{abstract}
azizjthoriq@yahoo.com This research examines the implementation of gender segregation in AtThoriqiyah Islamic Boarding School, in particular. Where this is based on Islamic values so as not to mix between men and women to avoid immorality. However, it cannot be denied that the application of segregation has also triggered the emergence of taboo behaviors and even far from the value of appropriateness. This study uses a descriptive-qualitative approach with the category of field research (field research). Data were collected by direct observation, interviews, and documentation study. The results of this study indicate the emergence of a variety of santri behaviors as a result of the segregation of lodgings, namely positive behavior such as more active study and worship, as well as negative behavior such as jokes outside the limits of reasonableness, encouragement to date, and homosexual behavior. These negative behaviors occur because of the internal biological drive (libido) in the students which causes a disorganization of values, both religious values and politeness values, in order to vent their desires. So, it is necessary to revisit the application of segregation in pesantren given the many negative behaviors that can damage the image and values in the pesantren.
\end{abstract}

Keywords: Gender, Behavior, Homosexual Segregation

\begin{abstract}
ABSTRAK
Penelitian ini mengkaji tentang pemberlakuan segregasi gender di Pesantren At-Thoriqiyah, khususnya Dimana hal tersebut disandarkan pada nilai-nilai keislaman agar tidak bercampur antara laki-laki dan perempuan untuk meghindari kemaksiatan. Namun tidak dipungkiri bahwa pemberlakuan segregasi tersebut juga memicu munculnya perilaku-perilaku yang tabu dan bahkan jauh dari nilai kepantasan. Penelitian ini menggunakan pendekatan deksriptif-kualitatif dengan kategori penelitian lapangan (field research). Data dikumpulkan dengan pengamatan langsung, wawancara, dan studi dokumentasi. Hasil penelitian ini menunjukkan munculnya beragam perilaku santri akibat dari segregasi pemondokan, yakni perilaku positif seperti semakin giatnya belajar dan beribadah, juga perilaku negatif seperti candaan di luar batas kewajaran, dorongan untuk berpacaran, dan perilaku homoseksual. Perilaku-perilaku negatif itu terjadi sebab dorongan internal bilogis (libido) pada diri santri yang menyebabkan disorganisasi nilai, baik nilai agama maupun nilai kesopanan, demi melampiaskan hasratnya. Sehingga butuh tinjauan kembali tentang pemberlakuan segregasi di pesantren mengingat banyaknya perilaku negatif yang bisa merusak citra dan nilai-nilai di pesantren.
\end{abstract}

Kata kunci: Segregasi Gender, Perilaku, Homoseksual

\section{PENDAHULUAN}

Pemberlakuan segregasi gender di pesantren diejawantahkan dari nilai-nilai keislaman agar tidak berbaur antara laki-laki dan perempuan yang bukan mahram. Hampir seluruh pesantren di Indonesia, baik yang mempertahankan ajaran salaf maupun yang khalaf (modern), masih memberlakukan segregasi tersebut. Sebab hal itu sudah dipandang sebagai ciri khas dari keberadaan pesantren (Dzulkarnain, 2012).

* Copyright (c) 2021 Thoriq Aziz Jayana

This work is licensed under a Creative Commons Attribution-ShareAlike 4.0 International License.

Diterima: 14 Maret 2021; Revisi: 22 Maret 2021 ; Disetujui: 28 Maret 2021 
Demikian pula yang terdapat di Pondok Pesantren At-Thoriqiyah, Pamekasan, yang memberlakukan segregasi pemondokan (segregasi gender) sebagai implementasi nilai ortodoksi keislaman. Namun tidak bisa dipungkiri bahwa kebijakan tersebut bisa membawa dampak positif dan negatif (yang bersifat tabu) terhadap perilaku santri. Hanya saja hasil penelitian-penelitian sebelumnya tidak banyak yang berupaya mengungkap secara komprehensif tentang perilaku-perilaku tersebut, baik yang positif maupun negatif, bahkan cenderung tabu untuk mengungkapkannya (Rahmawati, 2015; Susanto \& Muzakki, 2017; Yanti, 2019).

Seperti hasil penelitian yang dilakukan oleh Evi Muafiah (2018), dalam penelitiannya "Realitas Segregasi Gender di Pesantren", memaparkan bahwa kebijakan pemisahan pengasramaan dan lembaga pendidikan (single sex education) di pesantren memberikan dampak positif bagi santri, terutama dalam aspek peningkatan akademik dan sifat kemandirian. Namun penelitian ini hanya mampu mengungkap aspek positifnya saja, dan terkesan tabu untuk mengungkap hal-hal negatif dibaliknya.

Sementara dalam penelitian Sudradjat \& Triyoga (2016), dalam jurnal ilmiahnya, "Segregasi Gender dalam Organisasi Spasial Pesantren-Pesantren Besar di Pulau Jawa", menyebutkan bahwa dengan pemberlakuan segregasi gender di pesantren berdampak negatif pada penciptaan ruang kehidupan yang berkeadilan, seperti tingkat toleransi dan kesetaraan gender yang terabaikan. Sehingga menurut Sudrajat dibutuhkan pembaharuan dalam menata konsep segregasi pesantren yang lebih toleran, tidak terlalu ortodoksi. Namun menurutnya, menghapus segregasi secara total bukanlah langkah yang tepat, sebab akan menghilangkan ciri khas kepesantrenan. Hanya saja dalam penelitian ini lebih fokus pada kesetaraan gender semata, bukan untuk mengungkap perilaku-perilaku kompleks yang muncul dari kebijakan segregasi di pesantren.

Lain halnya dengan penelitian yang dilakukan oleh Rahmatullah \& Azhar (2018) yang berjudul "Pesantren dan Homoseksualitas Kaum Santri", dan penelitian oleh Iskandar Dzulkarnain (2006) yang berjudul "Perilaku Homoseksual di Pondok Pesantren". Keduanya memaparkan tentang beragam perilaku santri yang menunjukkan kecenderungan homoseksualitas (penyuka sesama jenis). Meski tidak secara eksplisit penelitian ini mengaitkan hal tersebut dengan segregasi gender. Hanya saja tidak begitu mendalam melihat keterhubungan sebab-akibat bagaimana kebijakan segregasi tersebut sehingga menimbulkan perilaku homoseksual santri.

Memperhatikan realitas pesantren dalam memberlakukan segregasi gender yang terlalu ortodoksi, dan mempertimbangkan hasil temuan sebelumnya yang kurang komprehensif mengkaji atas pengaruh segregasi tersebut terhadap beragam perilaku santri, Penelitian ini bertujuan untuk melihat lebih detail bagaimana pengaruh itu bisa terjadi, dan perilaku apa saja yang dapat muncul dari pengaruh tersebut. Penelitian ini diharapkan bisa dijadikan bahan pertimbangan bagi pembuat kebijakan pesantren, yakni kiai, dalam membuat keputusan yang lebih toleran (moderat) dalam memberlakukan segregasi di pesantren. Disamping itu, secara akademis, kajian ini diharapkan mampu menjadi bahan rujukan dalam mmengembangkan wacana tatanan sosial yang lebih mapan dan berkeadilan.

\section{METODE PENELITIAN}

Penelitian ini jika dilihat dari lokasi sumber data termasuk kategori penelitian lapangan (field research). Dan ditinjau dari segi sifat-sifat data maka termasuk dalam penelitian kualitatif (Moleong, 2012). Adapun pendekatan yang digunakan ialah etnometodologi, yakni metode keilmuan untuk mengetahui lebih mendalam tentang realitas sosial yang terjadi pada individu atau masyarakat (Sulanam, 2017). Agar hal yang diteliti dapat terungkap dengan jelas, maka dilakukan pengamatan langsung, wawancara mendalam, dan dokumentasi guna memperoleh data yang terperinci. 
Adapun sumber data dalam penelitian ini terdapat dua sumber: pertama, sumber data primer dan sekunder. Sumber data primer diperoleh peneliti melalui observasi tersembunyi (hidden observation) dan wawancara mendalam (indepth interview) dengan informan. Informan dalam penelitian ini adalah lima santri putera remaja yang berusia antara 12-22 tahun (diambil secara purpose sampling yang masih dalam masa remaja) dan tiga ustad, dan terkhususnya kiai pengasuh. Serta adakalanya peneliti akan mewawancarai alumni pesantren At-Thoriqiyah (jika sekiranya dibutuhkan saat membutuhkan informasi lebih lanjut)

Sedangkan sumber data sekunder sebagai sumber data pendukung. Dalam hal ini termasuk kategori bahan tambahan tersebut seperti sumber buku dan majalah ilmiah, sumber dari arsip, dokumen pribadi, dan dokumen resmi pesantren At-Thoriqiyah, dan segala bahan pendukung yang dapat menunjang dalam penelitian. Setelah data terkumpul, maka selanjutnya ialah dilakukan analisis data dengan metode analisis deskriptif (naratif). Dalam menganalisis data yang terkumpul dari hasil wawancara, observasi, dokumentasi, kemudian peneliti menginterpretasikan dengan teknik koding agar pemaparan hasil penelitian bersifat utuh dan terterpercaya (Sugiyono, 2019).

\section{HASIL DAN PEMBAHASAN}

\section{Tinjauan Tentang Segregasi}

Diberlakukannya segregasi di pesantren merupakan suatu tatanan sosial dalam menciptakan lingkungan yang dianggap religius. Yang dibentuk oleh pesantren atas dasar penafsiran akan nilai/norma dan penafsiran atas hukum-hukum agama yang mengharuskan adanya pembatasan hubungan/interaksi laki-laki dan perempuan yang bukan mahramnya (Asrohah, 2013). Tatanan sosial tersebut dapat dilihat dari pemisahan pemondokan atau pengasramaan santri putra dan putri, atau dalam hal ini kita kenal pula dengan segregasi pemondokan santri.

Sebagaimana dalam tatanan sosial pesantren pada umumnya, di Pesantren At-Thoriqiyah juga memberlakukan tatanan sosial yakni dengan memberlakukan aturan segregasi pemondokan/pengasramaan santri putra dan santri putri. Dimana letak santri putri diletakkan lebih tertutup dibandingkan pemondokan bagi santri putra, dan diberikan pagar pembatas tinggi yang terbuat dari dinding kokoh (dokumentasi: maping pesantren, 2019).

Peletakan pemondokan santri putri lebih tertutup bukan karena tanpa alasan, yakni agar tidak mudah dimasuki oleh orang luar mapun santri putra sekalipun, selain itu agar santri putri tidak bebas berkeliaran. Sedangkan pemondokan bagi santri putra diletakkan lebih 'keluar' yang dekat dengan jalan raya, dalam artian lebih longgar yakni dengan maksud karena santri putra bisa menjaga diri dari kalangan luar. Namun, demikian santri putri juga dilarang untuk memasuki pemondokan santri putra, dan demikian pula sebaliknya, santri putra dilarang untuk memasuki pemondokan santri putri.

Selain alasan keamanan bagi para santri, dan tidak inginnya terjadi hal-hal yang tidak diinginkan oleh pihak pesantren, juga pemberlakuan tatanan sosial sebagaimana diatas, dimaksudkan sebagai pengaplikasian dari nilai-nilai/aturan-aturan agama Islam, yakni dilarangnya (diharamkannya) hubungan/pergaulan laki-laki dan perempuan yang bukan mahram, misalnya tentang dilarang berikhtilath (bercampurnya laki-laki dan perempuan dalam berbagai kegiatan). Larangan-larangan tersebut diberikan bagi kaum muslim laki-laki dan perempuan yang sudah baligh. Dikarenakan Islam ingin menjaga kemuliaan dan kehormatan bagi keduanya. Dan perintah tersebut semata-mata berfungsi untuk menutup akses-akses yang dapat menyebabkan terjadinya ikhtilat dan/ zina (Mohammad Muchlis 
Solichin: 2013). Sebagaimana penjelasan kiai pengasuh, ketika peneliti bertanya tentang "Mengapa pondokan harus dipisah antara santri laki-laki dan santri putri?

"Sebenarnya ini merupakan upaya menjauh dari perbuatan maksiat. Karena dalam Islam sendiri terdapat aturan agar orang Islam laki-laki dan perempuan tidak boleh bercampur, padahal bukan muhrim. Selain itu, sebenarnya ini agar terhindar dari perbuatan zina, kalau dalam Islam, kan, ada 'La taqrabuz zina' (Janganlah mendekati zina), kan begitu. Maka dari itu, salah satu cara ialah dipisahlah pemondokan atau dalam istilah fiqih diberlakukan 'hijab' yang artinya pembatas." (wawancara dengan kiai pengasuh: 2019).

Dalil syar'i yang digunakan berdasarkan alasan Kiai ialah pada Al-Quran Surah Al-Isra' [17]: 32, yang artinya; "Dan janganlah kamu mendekati zina; sesungguhnya zina itu adalah suatu perbuatan yang keji dan suatu jalan yang buruk" (Al-Isra' [17]: 32)

Pemberlakukan pemisahan atau hijab tersebut nampaknya bukan hanya berlaku pada pemondokan atau pengasramaan saja, sebab dalam pendidikannya sekalipun juga dierlakukan pemisahan tempat belajar, yakni ada sekolah/madrasah untuk putra dan sekolah/madrasah untuk putri. Sedangkan berkaitan dengan peribadatan, ternyata pondok At-Thoriqiyah menerapkan dua tempat ibadah khusus untuk santri putra dan santri putri. Kalau santri putra sholat berjamaahnya di masjid AtThoriqiyah yang secara bebas juga digunakan oleh masyarakat sekitar untuk beribadah juga. Sedangkan bagi santri putri sholat berjamaah di musholla yang berada di dalam lokasi pemondokan santri putri, musholla tersebut hanya digunakan oleh santri putri yang diimami oleh nyai pengasuh (istri kiai pengasuh) atau pengurus santri putri sedangkan masyarakat luar tidak bisa sembarangan masuk ke dalamnya.

Tatanan sosial di pesantren bukan hanya difokuskan pada pemisahan (segregasi) pemondokannya saja, akan tetapi dampak yang lain ialah terbentuknya konstruksi interaksi sosial dimana terjadinya hubungan yang intensif sesama jenis bagi santri. Santri putra intensif hubungannya dengan sesama santri putra, sedangkan santri putri intensif hubungannya dengan sesama santri putri. Selain itu adanya larangan dari pihak pesantren dimana pesantren sangat membatasi bahkan memperketat terhadap interaksi santri yang bukan mahramnya. Dan hal tersebutlah yang menjadi alasan dalam beberapa wawancara sebagai bentuk munculnya perilaku bagi santri.

\section{Ragam Perilaku yang Muncul Akibat Segregasi}

\section{Giat Belajar dan Lebih Rajin Beribadah}

Ketika peneliti bertanya kepada seorang santri, bernama Khalid, yang menjadi objek penelitian, tentang "Apa yang Anda rasakan jika dipisah pemondokan dengan santri perempuan?". Dia menjawab lebih giat belajar dan lebih rajin beribadah, terutama mereka bisa terhindar dari maksiat ikhtilat. Seperti pada umumnya, dimana santri suka mencari perhatian dari lawan jenisnya, maka dengan diberlakukannya segregasi ini menjadikan mereka lebih berfokus dalam menjalankan peribadatan dan belajar kitab.

"Yang jelas bisa terhindar dari maksiat, kak. Jadinya kita bisa lancar dan khusu' dalam beribadah tidak lirik-lirikan dengan santri putri. Sholat bisa khusuk. Kalau seandainya disatukan pastinya tidak akan khusu', yang ada hanya saling lirik-lirikan. Bercanda saling cari perhatian, santri putra cari perhatian santri putri, sedangkan santri putri mencari perhatian santri putra. Jika sudah demikian, maka suasananya hanya ramai" (wawancara dengan santri Khalid: 2019).

Sedangkan dalam pengamatan peneliti, saat beribadah (sholat berjamaah) santri diimami oleh kiai [kadangkala oleh ustad pengurus] mereka betul-betul khusuk dalam menjalankan ibadahnya, tanpa ada 
yang melirik-lirik atau mencari perhatian santri putri, karena memang lokasi sholat santri putri berada jauh dari lokasi santri putra, tanpa ada suara-suara perempuan yang bisa saja akan berbeda, menjadi lebih ramai, jika mereka disatukan dalam peribadatannya (hasil observasi: 2019).

Dalam hal ini, perilaku santri lebih religius dan fokus belajar dalam artian mereka tidak membutuhkan suatu apresiasi dari lawan jenisnya. Sebab pada masa remaja lebih suka untuk menarik perhatian lawan jenisnya, dengan kata lain mereka suka mencari-cari perhatian. Mereka merasa dengan segregasi itu dapat menjalankan kewajibannya dengan tingkat kekhusukan dan kefokusan yang baik. Jadi bagi santri alasan dipisahkan pemondokan tersebut memberikan dampak positif yakni perilaku mereka lebih religius, saat sholat bisa khusuk dalam beribadah dan bisa fokus dalam belajar, karena sekolah mereka juga diintensifkan sesama santri putranya saja, demikian pula dengan tempat peribadatan mereka yang juga dipisahkan.

Artinya, para santri putra [remaja] ini merasa lebih religius dalam kehidupannya dengan tatanan sosial yang demikian. Hal ini dapat dipahami sebagai 'Orientasi menjaga sistem' (system maintenance orientation). Dimana pada usia remaja tingkah laku moral ditujukan untuk mepertahankan norma-norma tertentu. Remaja yang taat beragama akan berusaha agar ia rajin bersembahyang supaya agama itu sendiri bisa berkelanjutan atau karena ia merasa perlu hidup dengan berpedoman pada agama. Sedangkan di pihak lain, ia mungkin memilih norma-norma kawan-kawan sekelompoknya karena norma itulah yang berlaku di lingkungannya dan ia mengikuti norma-norma itu sebagai ukuran moralnya karena ia beranggapan bahwa kelompoknya itulah yang patut dijadikan pedoman (Rahmatullah \& Purnomo, 2020).

Pada usia remaja, mores atau moral merupakan suatu kebutuhan tersendiri karena mereka sedang membutuhkan pedoman dalam rangka mencari jalannya sendiri. yang mana pedoman tersebut dibutuhkan juga untuk menumbuhkan identitas dirinya, menuju kepribadian yang matang. Dengan demikian, perilaku religius dengan salah satu bagian penting di dalamnya (mores) menjadi salah satu faktor pengendali terhadap perilaku remaja. Demikian dalam pesantren, pemisahan pemondokan tersebut dapat memberikan arti kepada remaja sebagai salah satu upayanya dalam berperilaku religius. Dimana agama dapat menstabilkan tingkah laku dan bisa menerangkan mengapa seseorang berada di dunia, khususnya bagi remaja yang sedang mencari identitas dirinya.

\section{Candaan Di Luar Batas Kewajaran}

Sebelumnya perlu dipertegas bahwa batas-batas kewajaran yang dimaksud di atas ialah suatu batasan dalam percandaan yang dapat diterima secara umum (kebudayaan dan norma sosial-agama). Sebagian orang terkadang kebablasan dalam bercanda hingga melanggar norma dan moralitas, yang jelas tidak pantas untuk diterima secara luas/umum oleh masyarakat. Dia memiliki maksud buruk dalam bercanda, sehingga bisa menjatuhkan wibawa dan martabat orang lain di depan orang banyak. Termasuk pula perkataan yang dapat menyinggung orang lain, perkataan kotor, menghina, dan perkataan melecehkan.

Di pesantren, terbiasa hidup bersama secara intensif dalam pemondokan, menyebabkan personal santri memiliki ikatan emosionalitas yang erat dengan santri lain. Kedekatan mereka menggambarkan keakraban yang sangat baik, mereka tidak sungkan untuk meminjam dan memberi pinjaman pakaian (sarung ataupun baju), mereka makan bersama, bahkan mandi sekalipun mereka tidak sungkan untuk bersama. Itulah salah satu bentuk emosional kedekatan santri satu sama lain yang merasa saling memiliki.

Namun, disamping itu ada satu hal yang sangat dipeneliti yakini dengan adanya dampak negatif yang terkadang terabaikan oleh mereka sendiri. Yakni adanya perilaku "ngalama"' atau terlalu berlebihan dalam candaan, over kidding. Seperti menelanjangi (membuka) sarung temannya di depan teman- 
temannya yang lain, memegang atau meremas payudara/dada temannya, dan mungkin masih banyak perilaku sejenis. Perilaku seperti hal diatas bagi keseharian santri dianggapnya sebagai sesuatu yang lumrah, mereka tidak merasa tabu akan semua hal itu. Hanya saja jika santri merasa kesal karena terlalu 'kelewatan' akan candaan tersebut, kadangkala bisa membuat mereka marah dan berbalas dendam (hasil observasi: 2019)

Kedekatan secara emosionalitas antara santri yang satu dengan santri yang lain terkadang membuta mereka sangat akrab. Keakraban tersebut kadangkala membuat mereka lebur dalam canda yang sebenarnya keluar dari nilai-nilai moralitas, atau lebih pas nya bahwa mereka telah berperilaku diluar batas moralitas. Seperti terucapnya kalimat-kalimat ejekan yang semestinya tidak patutu untuk diucapkan. Misal, "Pala'én abâ'na énga' ronjhângan" (Kelaminmu seperti palang pintu) untuk menggambarkan bahwa kelamin temannya berukuran besar sekali (hasil observasi: 2019).

Bahkan, peneliti juga menemukan dan mendengar santri yang berucap, 'Palang dâgghi' abâ'na, yâ, engko' dalaq colo'na bân" (Awas nanti kamu, ya, peneliti dalaq mulutmu). Kata dalaq sendiri adalah kata berbahasa Madura yang sudah lumrah untuk mengambarkan perilaku homoseksual atau queer sesama jenis. Hal ini bisa semakin memperkuat akan adanya perilaku homoseksual dikalangan para santri. Sebab istilah-istilah tersebut tak akan dapat lumrah dikalangan santri jika selama ini belum ada perilaku akan hal itu. Artinya, istilah itu ada untuk menggambarkan perilaku yang ada.

Candaan lain yang dapat ditemukan dalam kehidupan santri ialah terkait rimming yang mana kadangkala santri memeluk tubuh santri lainnya dalam keadaan telanjang dada [setelah mandi biasanya] atau bahkan kadangkala santri menelanjangi temannya disaat berganti sarung, misalnya, sarung temannya dipeloroti hingga temannya merasa malu karea dilihat santri lain. Sedangkan santri yang mempeloroti sarung temannya tadi tidak ada rasa sedikitpun menyesali perbuatannya, bahkan terkadang setelah mempeloroti sarung temannya; santri tadi meneriaki santri yang dia peloroti sarungnya sehingga banyak santri lain yang melihatnya. Dengan perkataan, "Ajjhâ' abângkang è dinna', Mat" (Jangan telanjang disini, Mat) padahal dia yang menelanjangi temannya (hasil observasi: 2019).

Candaan-candaan seperti diatas bagi sesama santri adalah lumrah walaupun secara tatakrama hal itu tidak patut untuk dilakukan. Kemungkinan besar hal tersebut disebabkan karena mereka secara intensif selama dua puluh empat jam berinteraksi dengan sesama santri sehingga candaan atau over kidding pasti akan ditemukan. Kehidupan komunal para santri juga memberikan pengaruh akan saling terbukanya sifat para santri dengan tidak ada sesuatu yang perlu untuk ditutupi dalam kalangan mereka.

Dalam pandangan ilmu psikososial, tatkala telah terbentuk suatu lingkungan sosial primer, seperti di pesantren, maka kedekatan tiap-tiap anggota kelompoknya sangat terasa erat dimana hal ini ditopang oleh hubungan psikologis dan sosiologis sehingga mereka merasa sama-sama memiliki dan melindungi satu sama lain, canda tawa, dan keakraban, serta kebebasan mereka terhadap yang lain sangat terbuka (Kartono, 1919).

Bahkan perilaku-perilaku yang diluar batas kepantasan sekalipun dianggapnya sebagai candaan yang lumrah dan 'mentradisi'. Hal inilah yang menyebakan para santri dengan lingkungannya menjadi sangat erat dan tidak ada yang perlu untuk dipermasalahkan, dengan kata lain dimana hal ini disebabkan oleh berakhirnya hubungan emosional yang akrab (ending a close emotional relationship) (Dzulkarnain, 2012).

Namun, hal itu tidak dapat dijadikan sebagai pembenaran akan kebiasaan candaan tersebut. Sebab tidak ingin adanya kebiasaan seperti itu menjalar dan ikut terbiasakan dalam keseharian santri ketika di masyarakat nanti. Sehingga bisa saja sebenarnya bagi pesantren dengan memberlakukan sanksi bagi santri yang ketahuan dalam hal tersebut. 


\section{Melanggar Aturan dan Pacaran}

Awalnya, peneliti sudah mendengar bahwa pondok At-Thoriqiyah ini disebut sebagai 'Pondok Jodoh" karena di pondok tersebut menerapkan aturan 'tidak tertulis' bagi santri yang ketahuan berpacaran, maka diberikan dua pilihan sanksi, yakni pertama dikembalikan kepada orang tua/wali, atau kedua, diberikan pilihan jika ingin terus nyantri maka harus bertunangan dengan perempuan/pria yang dipacarinya. Namun sebelumnya, sanksi digunduli kepalanya (bagi santri putra) dan dijemur di depan musholla (bagi santri putri) tetap berlaku untuk pelanggaran ini. Dan hal itu merupakan kebijakan dari kiai selaku pemegang kebijakan tertinggi dan telah diberlakukan sejak dulu semasa dimulainya pesantren At-Thoriqiyah.

Maka dari itu, bagi peneliti, sangat mudah untuk menemukan santri yang pernah melanggar karena berpacaran, yakni dengan bertanya kepada santri lain siapa saja santri yang sudah bertunangan. Setidaknya, jika santri itu masih setingkat 'Aliyah dan sudah bertunangan, besar kemungkinan bahwa dia pernah berpacaran, kemudian diketahui oleh pesantren, dan harus menerima sanksi bertunangan dengan pacarnya itu (hasil observasi: 2019).

Ketika peneliti bertanya tentang hal berpacaran, santri Wadud menjawab,

"Kan, saya normal kak, lagi pula di pondok itu kan hubungan antara wanita dan laki-laki dilarang bertemu, makanya sebagai orang normal saya berusaha ngintip-ngintip (ngelirik) santri wanita yang keluar [berada di jalan]. Itu kan [maksudnya pembedaan pemondokan] semakin membuat saya penasaran, hanya ingin tahu siapa saja santri yang cantik. Bukan hanya santri putra saja yang berusaha untuk mengetahui atau melanggar, tapi santri putri juga banyak yang berbuat demikian. Artinya, selama ada keinginan untuk berpacaran maka apa saja bisa dilakukan sekalipun melanggar. Santri yang banyak diperbincangkan itu biasanya yang banyak menjadi incaran para santri lawan jenisnya." (hasil wawancara dengan santri Wadud: 2019).

Sementara menurut penuturan santri Ahmad,

"Anak remaja. Kan, ingin tahu cewek. Kita kan santri yang sulit bertemu dengan cewek. Jadi ada tantangan tersendiri untuk bertemu cewek. Kalau pengurus disini kan boleh masuk ke kawasan putri, jadi dari buah pembicaraan itu kita dapatkan kabar bahwa santri si ini sedang menjadi pembicaraan di putri. Nah, kita kan pastinya sebagai remaja berebutan ingin tahu dan ingin memacari si santri putri ini yang menjadi primadona di sana. Yang bisa mendapatkan santri primadona itu kan berarti dia adalah pria sejati. Jadi ada tantangan tersendiri lah untuk berpacaran di pesantren, kalau berpacaran diluar mah biasa, tidak ada straf, tapi kalau dipesantren itu berpacaran baru luar biasa karena ada aturan" (hasil wawancara dengan santri Ahmad: 2019).

Jadi, dapat dipahami bahwa dengan diberlakukannya segregasi pesantren yang demikian justru menjadi tantangan bagi mereka (masa remaja) untuk melanggar dengan cara berpacaran. Dengan kata lain bahwa dengan diberlakukannya segregasi pesantren justru memunculkan pelanggaran-pelanggaran yang tabu bagi pesantren, seperti pacaran. Mereka merasa tertantang untuk berpacaran, besar kemungkinan hal tersebut karena mereka masih remaja yang memiliki drive atau libido untuk melampiaskan keingintahuannya terhadap lawan jenis. Namun karena lingkungan yang tidak mendukung, maka mereka akan semakin tertantang untuk melakukan pelanggaran asalkan apa yang menjadi drive mereka tersampaikan.

Ketika peneliti bertanya bagaimana cara ia berpacaran, maka santri Ahmad menjawab,

"Bisa dengan cara SMS-an kak, kalau pegang Hp tapi belum diketahui pengurus, tapi kalau SMS-an pasti suatu saat diketahui pengurus, kecuali kita pinjam HP milik pengurus. Atau lewat cara nulis surat-suratan kepada santri putri, biasanya saya letakkan di bangku saat madrasah kalau meraka ada acara kursus sholawatan di MI. Pengurus yang kenal dekat dengan kita akan memberikan 
pinjaman HP-nya secara bebas kepada santri. Sehingga santri bisa dengan bebas pula untuk bisa melanggar, seperti SMS ataupun bahkan untuk melihat hal-hal yang tak senonoh di internet. Atau facebookan dengan santri putri. Sebab santri putri juga ada yang demikian, mereka bisa membalas SMS kita artinya kan disana mereka juga pegang HP entah milik pengurus atau membawa sendiri dari rumahnya dengan cara diumpetin." (Hasil wawancara dengan siswa Ahmad: 2019).

Beraneka cara yang mereka lakukan untuk bisa mengungkapkan rasa cinta kepada santri putri, demikian santri putri yang juga membalas surat cinta yang dikirimkan kepadanya. Walaupun sebenarnya mereka sadar bahwa perbuatan tersebut termasuk pelanggaran berat dalam aturan pesantren, namun karena mereka dengan jiwa labil (masa remaja) yang menggebu-gebu sehingga apapun akan mereka lakukan untuk tersampaikannya hasrat tersebut.

Hal itu bisa dipahami, sebab pada usia remaja, ada kecenderungan pada remaja untuk mengambil posisi yang sangat ekstrem dan mengubah kelakuannya secara drastis, akibatnya sering muncul tingkah laku radikal dan memberontak dikalangan remaja atas aturan/norma yang ada (Aviyah \& Farid, 2014). Didorong pula dengan labilitas yang dialami pada masa remaja sehingga membuat para remaja dalam kemelut ketidakpastian yang yang membawa seperangkat persoalan yang berkaitan dengan peranan sosial. Pada saat remaja menghadapi semua keprihatinan tersebut, yaitu pada saat dimana remaja sedang tidak siap untuk berkutat dengan kerumitan, berikutnya muncul faktor-faktor yang lain yang menimpa dirinya, dimana remaja dituntut untuk membuat suatu pilihan (Aviyah \& Farid, 2014).

Selain itu, faktor lain, mulai dari perubahan fisik pada remaja, terutama organ-organ seksual, yang memengaruhi perkembangan emosi atau perasan-perasaan dan dorongan-dorongan yang baru di mana sebelumnya tidak pernah dialami, seperti perasaan cinta, rindu, keinginan untuk berkenalan lebih intim dengan lawan jenis. Perasaan dan dorongan tersebut sering kali menjadi masalah besar yang membawa malapetaka bagi perkembangan remaja selanjutnya (Saputro, 2018).

Oleh karenanya, maka tidak dapat dipungkiri bahwa beberapa santri di pondok pesantren memilih untuk melanggar aturan hanya demi merealisasikan dan menyalurkan hasrat keingintahuannya kepada lawan jenisnya, yakni dengan jalan berpacaran. Faktor internal dan faktor eksternal (tatanan sosial pesantren) sebagai akibat dari produksi hormonal tadi dan juga pengaruh lingkungan, yang menyebabkan santri berperilaku berpacaran dan menimbulkan dorongan dan perasaan baru.

Tidak jarang jika kelabilan, kegelisahan, ketidakpastian, dan selalu menginginkan hal-hal yang praktis (tidak rumit) pada masa remaja tatkala dihadapkan dengan lingkungan atau situasi sosial yang ada dan tidak dapat mewakili keinginan remaja, maka ada kalanya remaja akan melakukan perbuatan/perilaku yang menyimpang atau dikenal dengan kenakalan remaja. Hal tersebut lah yang mungkin dimaksudkan oleh Kartini Kartono dengan istilah delinkuensi situasional. Dimana delinkuensi ini dilakukan oleh anak (individu) yang normal, namun mereka banyak dipengaruhi oleh berbagai kekuatan situasional, stimuli sosial, dan tekanan lingkungan, yang semuanya memberikan pengaruh "menekan-memaksa" pada pembentukan perilaku (Kartono, 1919).

Tekanan-paksaan yang dialami oleh santri (dengan tatanan sosial yang demikian) justru dianggap oleh santri yang merasa 'tertekan' dengan hal tersebut sebagai suatu tantangan tersediri, selain untuk mencari identitas dirinya dan kemampuan dirinya 'siapa yang mampu untuk berpacaran', maka dianggaplah oleh kawan sejawatnya sebagai pria pemberani.

\section{Perilaku Homoseksual Di Kalangan Santri}

Perilaku seksual santri yang ada di Pesantren At-Thoriqiyah pada dasarnya tidak berbeda dengan jauh dengan perilaku seksual pada masyarakat secara umum. Sebab mereka juga memiliki libido (secara 
biologis) dan hasrat untuk melampiaskan dorongan internalnya. Meskipun demikian, tidak dapat diukur seberapa tinggi dan seberapa rendahnya perilaku seksual seorang santri.

Bisa dipahami bahwa perilaku menyimpang itu terjadi karena social dizorganisation dimana nilainilai yang dianut oleh suatu komunitas/masyarakat (baik itu nilai sosial, budaya, dan agama) akan diselewengkan atau didisorganisasikan demi untuk memenuhi kebutuhan primer/dasarnya, seperti kebutuhan fisiologis yang tidak terealisasikan karena sarana atau lingkungan tidak mendukung untuk mendapatkan keinginannya, maka hal itu akan memancing individu untuk berperilaku menyimpang dengan tanpa lagi dipengaruhi oleh norma/nilai yang dianut oleh komunitasnya (Hawari, 2011).

Untuk mengatasi perilaku seksualnya itu, maka santri akan berupaya dengan tatanan sosial yang demikian untuk berperilaku homoseksual. Perilaku homoseksual sendiri diartikan sebagai liwath (sek lewat dubur), akan tetapi hal-hal yang menunjukkan adanya indikasi perilaku homoseksual itu beragam, seperti queer, rimming, menggesek-gesekkan tangannya ke pantat sejenisnya, meremas dada sejenisnya, meremas pantat temannya, berfantasi saat mandi bersama, berciuman dengan sejenisnya, dan banyak hal lain akan hal itu (Oetomo, 2001). Di Pesantren At-Thoriqiyah istilah homoseksual dikenal dengan istilah lâq- dâlâq. Dalam bahasa Madura memang terdapat entri dâlâq, yang diterjemahkan sebagai perbuatan homoseks lewat dubur. Bahwa bentuk dasar dâlâq itu dapat diberi imbuhan menjadi adâlâq: melakukan perbuatan homoseks, lâq- dâlâq (saling): melakukan perbuatan homoseks, serta kadâlâq: menjadi obyek dalam perbuatan homoseks. Istilah dâlâq dikalangan sanri nampaknya sudah terbiasa (hasil observasi: 2019).

Salah satu bentuk yang juga mendorong mereka berprilaku homoseksual ialah dengan terbiasanya mandi bersama secara telanjang. Hal itu disebabkan karena terbatasnya kamar mandi yang disediakan oleh pesantren, dimana hanya ada tiga kamar mandi yang harus melayani ratusan santri. Menyebabkan para santri harus mandi bersama dalam keadaan mandi bertelanjang. Hal itu dilakukan karena tidak mungkin dengan jadwal kegiatan yang padat, santri harus antri satu-satu menunggu giliran untuk mandi.

Sebagaimana wawancara dengan Ustad Kurdi. Peneliti bertanya,

"Kalau kamar mandinya hanya ada tiga, bagaimana kalau ada ratusan santri, apakah harus antri?". Ustad Kurdi menjawab, "Kadang ada santri yang mandi di sungai, ada juga yang mandi bersama di kamar mandi itu. Hal seperti itu sudah biasa hanya sebatas mandi, kan sama-sama cowok. Saya bertanya, "Apakah tidak ada kekhawatiran dari pengurus bahwa santri berperilaku menyimpang seperti laq-dalaq. Ustad AK menjawab, "Yah, saya tidak tahu akan hal itu, sebab saya kan tidak bisa pantau sampai ke dalam kamar mandi". (Wawancara dengan Ustad Kurdi: 2019).

Selain itu juga terbiasa perilaku-perilaku queer sesama jenis. Istilah queer menunjukkan perilaku yang menggambarkan hubungan sesama jenis guna melampiaskan hasrat seksualnya. Bentuk-bentuk perilaku queer dalam pesantren yang dapat peneliti temukan ialah menggesek-gesekkan tangan ke pantat santri yang diidamkan, meremas-remas dada/payudara santri lain, dan tidur telanjang dada lalu menyilangkan kaki ke santri lain yang sambil tiduran.

Ada pula perilaku queer yang lain, dimana santri disaat santai atau tidak ada kegiatan mereka dari pagi sampai siang waktunya dihabiskan untuk santai/istirahat, utamanya pada hari Jumat. Di dalam kamar, santri saling curhat sambil telentang tiduran, bertelanjang dada berhadap-hadapan miring ke kanan dan ke kiri. Santri tersebut santri senior yang mendengarkan curhatan santri junior. Disaat santri junior sedang khusuknya bercerita tentang pengalamannya, maka secara sengaja atau tidak, santri senior menyilangkan kakinya hingga bertumpu pada kaki santri junior. Sehingga paha mereka bergesekan. Dan hal itu tidak dihiraukan oleh santri junior. Perilaku tersebut dalam istilah seksualitas sesama jenis dikenal dengan hubungan penis sela paha (interfemoral) dan gesek-gesek (frottage). 
Hal ini sesuai dengan penuturan santri Yadi yang berkata,

"pesantren memiliki istilah berbeda tentang hal itu (homoseksual), yang dijadikan korban, itu biasanya anak yang lebih muda, putih bersih kulitnya. Ya, mungkin dalam benak mereka, dari pada berzina besar, lebih baik melampiaskan itu ke zina kecil, kan kalau 'main' bersama sesama jenis mungkin lebih ringan. Berciuman antara santri senior kepada juniornya yang masih polos, tampan, dan tidak tahu apa-apa itu adalah hal biasa. Terutama kalau malam Jumat atau hari libur. Para santri yang terkenal tukang dalaq berupaya mencari korban, dan bukan hanya mencari sendirian, tapi ada teman lainnya untuk mencari miril yang dianggapnya cocok dan tidak banyak melawan. Tapi, itu semua hanya terjadi saat mereka masih jadi santri, ketika keluar pondok banyak teman saya mengaku kembali normal sebab secara alamiah mereka memang adalah orang normal dan bukan homo. Hanya lingkungan saja yang membuat dan memaksa mereka untuk berperilaku homosek. Saya rasa semua pesantren yang menerapkan pemisahan pondok santrinya pasti hal seperti itu ada dan diangap biasa" (Wawancara dengan santri Yadi: 2019).

Di pesantren-pesantren di Jawa, hal ini dikenal dalam istilah miril (atau mairil—bahasa Jawa). Dialah santri yang lebih muda, berparas tampan, berkulit putih bersih, dan masih polos. Sehingga terjadi relasi antara santri junior santri senior ini, dimana santri junior atau miril membutuhkan perlindungan dari santri senior sehingga mereka merasa aman dan nyaman, sedangkan bagi santri senior hal ini dijadikan kesempatan untuk melampiaskan libido mereka. hal inilah terjadi hubungan attraction (ketertarikan).

Dari ikatan attraction tersebut dimana terdapat kecocokan kedua belah pihak dan saling diuntungkan, maka keduanya jadi cenderung tidak mau untuk bergaul atau terbuka dengan orang kecuali pasangannya. Hal ini pulalah yang memunculkan sifat melankolis (lemah lembut) bagi miril, maka dia membutuhkan seorang teman. Hubungan mereka suka sama suka dan secara diam-diam. Sebagai suatu the undercover yang tak perlu untuk diungkapkan ke khalayak umum (Dzulkarnain, 2012). Selain itu, berdasarkan keterangan santri alumni, bahwa melancarkan aksinya, mereka tidak hanya sendirian akan tetapi juga ada teman lain yang ikut berperan membantu untuk menemukan miril (bagi mereka yang tidak memiliki relasi dengan miril simpanan). Jika tidak menemukan miril bisa saja mereka akan berbuat perilaku homoseksual sesama temannya tadi. Keterbatasan kesempatan dan sulitnya mencari relasi seksual bagi mereka (terutama santri junior), telah menyebabkan semangat kesenangan seksual dengan melakukan sex for pleasure sesama santri junior atau santri angkatannya.

Terkait hal tersebut, memberikan suatu kesimpulan bahwa hal homoseksual di pesantren bukanlah hal yang tiada namun bukanlah arus utama dan bukan pula perilaku yang dilakukan oleh sebagian besar santri (mungkin hanya satu-dua/sedikit sekali santri yang berperilaku queer. Hal tersebut hanyalah fenomena kecil (the undergroud) yang tidak menjadi perbincangan secara keseharian di pesantren, sebab dianggap akan merusak citra dan nama baik pesantren. Meski demikian santri-santri yang berperilaku lâq- dâlâq atau queer tidak terima bila dirinya disebut sebagai homoseks. Sebab, beradasarkan penuturannya, mereka berbuat demikian hanya karena ingin melampiaskan hasrat seksualitas, bukan sebagai orientasi seksual. Artinya, mereka masih suka terhadap perempuan (lain jenis) hanya saja karena aturan pesantren yang begitu ketat dalam memberlakukan segregasi. Perilaku homoseksual santri hanya sebagai pelampiasan sebab paksaan lingkungan yang tidak mendukung. Sedangkan setelah mereka keluar dari pesantren, orientasi sesksualitas mereka tetaplah menjadi heteroseksual.

Jika kita mengacu pada kisah-kisah yang diungkapkan oleh para santri di pelosok nusantara dalam bentuk buku sebagai bentuk curahatan mereka. Sebenarnya ada beberapa buku yang bertemakan demikian, seperti buku Santri Sableng dan buku Mairil yang mengungkapkan kisah demikian (Al-Hamdi, 
2009; RIYANDESKA, 2006). Dan bahkan buku penelitian Dzulkarnan (2012). Hal ini semakin memperkuat bahwa perilaku homoseksualitas di pesantren adalah benar adanya, namun kedudukannya sangat tertutupi. Secara kajian ilmiah hal ini dapat dipersepsikan sebagaimana yang digambarkan oleh Sarwono (2019) dalam bukunya Psikologi Remaja mengungkapkan bahwa salah satu keluhan yang banyak dialami oleh para remaja adalah homoseksualitas. Homosek dapat terjadi begitu saja dari pengalaman yang sangat biasa (seperti saat berkemah sesama jenis saja mereka melakukan rimming kelamin atau handjob bersama) tau malah berkembang menjadi homoseksualitas di luar kemauan, artinya sudah menjadi orientasi seksualnya.

Seperti terjadinya perilaku homoseksual bagi para narapidana di penjara (all male environment), mereka hidup dalam satu tatanan sosial yang intensif bagi sesama jenis. Walaupun secara nilai/norma telah diatur bahwa hubungan seksual hanyalah dilakukan kepada lawan jenis, akan tetapi dengan sarana kehidupan yang demikian dimana hasrat seksualnya tidak tersalurkan pada lawan jenis akan menyalurkannya kepada rekan-rekannya yang sejenis. Para narapidana berbalik melakukan perilaku homoseksual tersebut dengan menyingkirkan norma/nilai yang berlaku untuk sekali-kali memenuhi kebutuhan seksualnya (Pujileksono, 2011).

Terkait dengan hal-hal internal dalam diri individu, dapat kita temukan banyak teori yang menjelaskan akah hal tersebut. Misalnya tentang teori dorongan (drive) yang bertitik tolak pada pandangan bahwa orgaisme itu memiliki dorongan (drive) tertentu, dimana dorongan-dorongan ini merupakan kebutuhan organisme yang dapat mendorong organisme untuk berperilaku (Munjiat, 2018). Yang dalam hal ini oleh Abraham Maslow dalam Hikma (2015) disebut sebagai 'kebutuhan fisiologis'. Kebutuhan fisiologis meliputi: makan, minum, pakaian, sex, rumah, dan kebutuhan bebas dari rasa sakit.

Maka dapat dipahami bahwa di pesantren tentang perilaku yang mengindikasikan homoseksualitas itu ada. Sedangkan perilaku homoseksual para santri tidak dapat diukur seberapa banyaknya, bahkan sangat sedikit sekali. Artinya, hal tersebut bukanlah sebagai arus utama dalam kehidupan pesantren, dan cenderung sangat ditutupi untuk diperbincangkan secara umum di luar pesantren.Sekalipun wejangan normalitas dan moralitas selalu melingkupi kehidupan keseharian santri akan tetapi perilaku sebagai dorongan "biologis" untuk melakukan hubungan seksual menjadi suatu yang lumrah. Hal ini semakin diperkuat dengan usia para sanri yang mondok yang secara mayoritas telah aqil baligh, atau sekitar usia remaja 12-21 tahun. Meskipun usia yang dibawahnya dan diatasnya juga masih banyak. Meskipun perilaku homoseksual (laq-dalaq) antar santri di pesantren pada awalnya lebih sebagai dorongan biologis terhadap masa keremajaannya. Akan tetapi, pada perkembangan selanjutnya perilaku tersebut lebih sebagai bentuk konstruksi subjektif mereka terhadap seksualitas. Hal ini diperkuat denga asumsi mereka bahwa mereka melakukan hubungan laq-dalaq sebagai sarana menjalankan kebebasan berperilaku dan kebersamaan dalam kesehariaan.

\section{SIMPULAN}

Diberlakukannya segregasi (pemisahan pemondokan) di pesantren, hal tersebut dapat memicu munculnya beragam perilaku santri. Mulai dari perilaku yang bernilai positif seperti semakin giatnya belajar dan rajin beribadah, namun tak bisa dipungkiri perilaku-perilaku negatif juga bisa bermunculan seperti candaan di luar batas kewajaran, dorongan untuk melanggar demi berpacaran, dan perilakuperilaku homoseksualitas di kalangan santri. Mengingat perilaku-perilaku negatif, terutama tentang homoseksualitas, yang justru membuat citra pesantren menjadi buruk. Yang seharusnya menanamkan nilai-nilai islami sebagai khas pesantren, justru terkesan sangat bebas dan terdekadensi dari nilai-nilai keislaman. Maka dalam hal ini, pemberlakuan segregasi di pesantren perlu ditinjau kembali. Apakah ia 
tetap layak dipertahankan sebagai sebuah tatanan sosial, atau perlu direaktualisasi? Disinilah kebijakan pesantren perlu dirumuskan kembali, dengan mempertimbangkan dan memperhatikan perkembangan psikologis para santri yang kebanyakan kaum remaja. Namun mengingat bahwa segregasi tersebut adalah bagian dari tatanan sosial di pesantren yang nampaknya tidak bisa dihilangkan dengan berlandaskan nilai-nilai keislaman, maka dalam hal ini perlunya upaya reaktualisasi tentang pembatasan interaksi sosial di kalangan santri laki-laki dan perempuan. Artinya, dibutuhkan aturan yang tetap mengikat, namun elegan dalam mengatur interaksi santri laki-laki dan perempuan.

\section{DAFTAR PUSTAKA}

Al-Hamdi, R. (2009). Santri sableng: sebuah catatan dari bilik pesantren. Leutika.

Asrohah, H. (2013). Transformasi Pesantren Pelembagaan Adaptasi, dan Respon Pesantren Dalam Menghadapi Perubahan Sosial. Jakarta: Dwiputra Pustaka Jaya.

Aviyah, E., \& Farid, M. (2014). Religiusitas, kontrol diri dan kenakalan remaja. Persona: Jurnal Psikologi Indonesia, 3(02).

Dzulkarnain, I. (2006). Perilaku Homoseksual di ondok Pesantren. [Yogyakarta]: Universitas Gadjah Mada.

Dzulkarnain, I. (2012). Dekonstruksi Sosial Budaya Alaq Dalaq Di Madura. Yogjakarta: Pararaton.

Hawari, D. (2011). Pendekatan psikoreligi pada trauma bencana. Badan Penerbit, Fakultas Kedokteran, Universitas Indonesia.

Hikma, N. (2015). Aspek Psikologis Tokoh Utama Dalam Novel Sepatu Dahlan Karya Khrisna Pabichara (Kajian Psikologi Humanistik Abraham Maslow). Jurnal Humanika, 3(15).

Kartono, K. (1919). Patologi sosial II: Kenakalan remaja. -.

Moleong, L. J. (2012). Metode Penelitian Kualitatif, cet. In Ke-30. Bandung: Remaja Rosdakarya Offset.

Muafiah, E. (2018). Realitas Segregasi Gender di Pesantren. Proceedings of Annual Conference for Muslim Scholars, Series 2, 1066-1078.

Munjiat, S. M. (2018). Peran agama islam dalam pembentukan pendidikan karakter usia remaja. AlTarbawi Al-Haditsah: Jurnal Pendidikan Islam, 3(1).

Oetomo, D. (2001). Memberi suara pada yang bisu. Galang Press Yogyakarta.

Pujileksono, S. (2011). Masalah-masalah di penjara dalam studi sosial. Jurnal Salam, 12(2).

Rahmatullah, A. S., \& Azhar, M. (2018). Pesantren Dan Homoseksualitas Kaum Santri (Studi Pada Pesantren Tua Salafiyyah dan Khalafiyyah di Kota Santri Jawa Timur). Jurnal Inferensi STAIN Salatiga Jurnal Penelitian Sosial Dan Keagamaan, 12.

Rahmatullah, A. S., \& Purnomo, H. (2020). KENAKALAN REMAJA KAUM SANTRI DI PESANTREN(TELAAH DESKRIPTIF-FENOMENOLOGIS). Ta'allum: Jurnal Pendidikan Islam, $8(2), 222-245$.

Rahmawati, A. (2015). Kepatuhan santri terhadap aturan di pondok pesantren modern. Universitas Muhammadiyah Surakarta.

RIYANDESKA, N. A. (2006). FENOMENA MAIRIL DAN NYEMPET DI PESANTREN: Pengalaman Mairil dan Nyempet Mantan Santri dan Dampak Psikologisnya. UNIVERSITAS AIRLANGGA.

Saputro, K. Z. (2018). Memahami ciri dan tugas perkembangan masa remaja. Aplikasia: Jurnal Aplikasi Ilmu-Ilmu Agama, 17(1), 25-32.

Sarwono, S. W. (2019). Psikologi remaja. Rajawali Pers.

Sudradjat, I., \& Triyoga, B. (2016). Segregasi Gender dalam Organisasi Spasial Pesantren-Pesantren Besar di Pulau Jawa. Journal of Regional and City Planning, 27(2), 91-102.

Sugiyono. (2019). Metode Penelitian Kuantitatif Kualitatif dan R\&D (Sutopo (ed.)). Alfabeta.

Sulanam, S. (2017). Etnometodologi (EM) dan Kajian dengan Pendekatan Etnometodologi. UIN Sunan Ampel Surabaya. 


\section{Khazanah Pendidikan Islam, Vol. 3 No. 2: 92 - 104}

Analisis dampak Segregasi Gender di Pesantren Terhadap Perilaku Santri Thoriq Aziz Jayana

Susanto, H., \& Muzakki, M. (2017). Perubahan Perilaku Santri (Studi Kasus Alumni Pondok Pesantren Salafiyah di Desa Langkap Kecamatan Besuki Kabupaten Situbondo). Istawa: Jurnal Pendidikan Islam, 2(1), 1-42.

Yanti, S. I. (2019). HUBUNGAN PERSEPSI PEMISAHAN KELAS LAKI-LAKI DAN PEREMPUAN DENGAN MOTIVASI BELAJAR PAI PADA PESERTA DIDIK SMK DARUT TAQWA PURWOSARI PASURUAN. Al Manar: Jurnal Pendidikan Islam, 1(1), 25-38. 